\title{
Law and Judicial Application of Digital Forensic Evidence in Nigeria
}

\author{
Felix E. Eboibi Inetimi Mac-Barango \\ Faculty of Law, Niger Delta University, WilberForce Island, Yenagoa, Nigeria
}

\begin{abstract}
The development of information \& communication technology has left the Nigerian polity to the application of technology infrastructure to daily activities. In essence, disputes arising from these activities may ordinarily not be effectively settled without applying electronic evidence in proceedings before the courts. The skills and knowledge of electronic evidence require the ingenuity of forensic experts or examiners for the purpose of bridging the gap that may arise in the mind of the courts. Does the Nigerian Law accept forensic expert evidence? Is every evidence expert evidence? Are there set down conditions before the courts for forensic expert evidence to be accepted or applied to proceedings before the courts? What nature of cases requires forensic evidence? This paper will demonstrate how information and communication technology has resulted in the application of digital devices by Nigerians and the nature of the impact it has .
\end{abstract}

Keywords: Digital Forensics Evidence, Forensics Examiners, Digital Forensics Experts, Law, Judicial application DOI: $10.7176 / \mathrm{JLPG} / 96-08$

Publication date: April $30^{\text {th }} 2020$

\section{Introduction}

The global advancement of information and communication technology (ICT) has resulted in the use of the computer, internet, e-mails, Facebook and social media in general in daily activities ranging from commercial services, research, online advertisement/marketing, electronic communication, online shopping, and news platforms to online banking. These devices contain digital evidence that can be of help should any dispute arise during usage in determining the justice or otherwise of a case (civil or criminal) brought before the court.

Digital evidence is any probative data or information that is stored or transmitted in an electronic manner, which can be useful to a party in the course of a court trial. Such evidence could have been deleted or incapable of being retrieved by owners of the device. Since the information is paperless or intangible, it takes the ingenuity of a forensics expert or examiner to be able to find such digital evidence with the application of forensic tools and techniques. In a nutshell, digital forensic evidence implies any nature of evidence recovered from digital media, which may be relied upon in the determination of civil or criminal disputes in courts of competent jurisdiction.

Digital forensic technology and evidence aid modern law enforcement and a veritable tool in the prosecution of criminals. It helps in the determination of the guilty and equally those who are innocent of crimes. Where the identity of a dead person is in issue, probably due to decomposition or destruction of the body beyond recognition, visual identification by a forensic dentist or forensic odontologist becomes necessary. ${ }^{1}$ Fingerprints analysis can aid the identification and detection of perpetrators of crimes. ${ }^{2}$ The application of DNA forensics enables crime laboratories and law enforcement agents to resolve violent crimes and sex offences through the identification of individual specimens. ${ }^{3}$ Computer forensics is "the use of scientifically derived and proven methods toward the preservation, collection, validation, identification, analysis, interpretation, documentation and presentation of digital evidence derived from digital sources for the purpose of facilitating or furthering the reconstruction of

Events found to be criminal...."4 Most crimes being committed today are with the use of mobile phones. Thus mobile or cell phone forensic enables investigators and forensics experts to preserve the data for collection and analysis. ${ }^{5}$ Handwriting analysis helps to identify the authors of disputed writing. ${ }^{6}$

When used effectively, it facilitates quick administration and dispensation of justice to the public. Amid the necessity of digital forensic evidence and its application in the determination of matters brought before the court, Is there a law regulating digital forensic evidence in Nigeria? Put in another form, how has the Nigerian Judiciary treated the application of digital forensic evidence and expert witnessing in the determination of matters brought

\footnotetext{
${ }^{1}$ Kehinde Adegbite, Law and Forensic: Techniques of Evidence Gathering and Case Presentation in Court, 11 October 2014, available at $<$ http://www.nigeriavillagesquare.com/articles/law-and-forensic-techniques-of-evidence-gathering-and-case-presentation-in-court.html $>$ Last accessed 10 October 2018

2 John W Bond, 'The Value of Fingerprint Evidence in Detecting Crime' (2009) 11 International Journal of Police Science Management, 77

3 Jay V Miller, 'The FBI's Forensic DNA Analysis Program' (1991) 60 FBI Law Enforcement Bulletin, 11 - .('DNA analysis' means analysis of the deoxyribonucleic acid (DNA) identification information in a bodily sample")

${ }^{4}$ A Road Map for Digital Forensic Research, Report from the First Digital Forensic Research Workshop (DFRWS), available at http://dfrws. org/2001/dfrws-rm-final.pdf in Ovie L Carroll and Stephen K Brannon and Thomas Song, 'Computer Forensics: Digital Forensic Analysis Methodology' (2008) 56 United States Attorneys' Bulletin 1

${ }^{5}$ Daniel Ogden, 'Mobile Device Forensics: Beyond Call Logs and Text Messages' (2017) 65 United States Attorneys' Bulletin, 11

${ }^{6}$ Andre A Moenssens, 'Handwriting Identification Evidence in the Post-Daubert World' (1997) 66 UMKC Law Review, 251,256
} 
before them? Can digital forensic evidence take the place of the presiding judge or magistrate, or are there circumstances where digital evidence can be discarded? Law and judicial application of digital forensic evidence for the purposes of this paper means legal framework or policy regulating forensic evidence generally and how the evidence can be useful or applied in proceedings in the administration of justice. Set down rules that have become notoriously accepted from conventional practice - i.e judicial notice that affects digital forensic evidence. Including Case law, Judges made rules and judicial precedent affecting forensic evidence or experts in Nigeria.

In the circumstances, this paper seeks to answer the questions above. The paper is set out with an introduction to the concepts of the paper. After that, it examines the historical legal foundation for digital forensics evidence and expert witnessing in Nigeria and how the development of technology has necessitated its application. In the absence of a specific legal framework for digital forensics in Nigeria, it identifies the legal basis for the acceptability of digital forensics

Evidence and witnessing by the Nigerian Courts. A review of the judicial and case law literature is made to show the attitude and approach of Courts towards digital forensic evidence. The paper further examines the nature of digital forensic evidence applied by the Nigerian Courts, while also determining to what extent is the relevance of forensic expert evidence.

\section{Nigeria's Legal Jurisprudence on Digital Forensic Evidence}

Generally, under the old Nigeria Law of Evidence, 1945, opinion evidence is irrelevant in trials before the Nigerian Courts. ${ }^{1}$ Section 66 of the hitherto Evidence Act, ${ }^{2}$ provides that the fact that any person is of the opinion that a fact in issue, or relevant to the issue, does not exist, is irrelevant to the existence of such fact except as provided for in sections 57 to $65 .^{3}$ The exceptions guarantee the admissibility of expert and non-expert opinions concerning foreign law, native law, and custom, points of science or art, the identity of handwriting or finger impressions, specific usages and tenets, the existence of the relationship of one person to another. What the exceptions imply is that the opinion of a digital forensic expert is only called upon where the inquiry is beyond the knowledge of a mind, e.g., the judges, magistrates, and judicial officials.

However, digital forensic evidence did not flourish in the Nigerian Courts within this period due to the controversy surrounding the interpretation of section 2 of the hitherto Nigerian Evidence Act 1945. Obviously, evidence generated from digital forensic examinations is generally electronic in nature. However, Section 2 of the hitherto Evidence Act, $1945^{4}$ defined "documents" to "include books, maps, plans, drawings, photographs and also includes any matter expressed or described upon any substance by means of letters, figures or mark or by one of these means, intended to be used or which may be used for the purpose of recording that matter." A careful and literal interpretation of the said section does not include electronically generated evidence or modern paperless or electronic storage devices. Arguably, the said definition is limited to documents that are tangible ie, something that is capable of being seen.

This presumably accounted for the limited application of digital expert evidence in resolving disputes in Nigeria within this period. In a 1946 case of $R$. v. Onitiri, ${ }^{5}$ the accused was convicted of forgery at the trial court. Upon his appeal, Vericity, C. J relied on expert evidence to affirm the conviction of the accused. Again, in the 1961 case of The Queen v. Akpan, ${ }^{6}$ where the accused who later appealed his conviction at the trial Court was alleged to have been involved in a burglary and stealing in breach of sections 411(1) and 390(4)(b) of the Criminal Code, respectively. The Court convicted the accused based on his finger-print impression that was discovered on the Louvre blade of the window. Due to the analysis of a person of experience and training.

The slow pace of development of computer \& information technology infrastructure in Nigeria may have also accounted for the limited application of digital expert evidence in Nigerian Courts. After the cases of $R$. v. Onitiri and The Queen v. Akpan, the Nigerian Supreme Court handed down two conflicting judgments on the admissibility of digital evidence, which arguably impacted the application of digital forensic evidence by the Nigerian Courts. ${ }^{7}$ The first notable pronouncement on the issue was made in 1969 by the Nigerian Supreme Court in Esso West Africa Inc. v. T. Oyegbola, ${ }^{8}$ where the court stated thus:

The law cannot be and is not ignorant of the modern business methods and

\footnotetext{
${ }^{1}$ Phiip O. Nwachukwu, Admissibility of the Opinion of a Computer Forensics Examiner as an Expert Evidence under Nigeria Law of Evidence. ${ }^{2}$ The Nigerian Evidence Act 1945 was reproduced as Cap E14, Laws of the Federation of Nigeria, 2004 now repealed by the Evidence of 2011, Section 68

${ }^{3}$ Ibid now Section $68-76$ of the Evidence Act, 2011.

${ }^{4}$ This law became the Nigerian Evidence Act Cap. E14 Laws of the Federation,(LFN) 2004 which remained largely untouched for more than 50 years.

${ }^{5} R$ v. Onitiri (1946) 12 WACA 58

${ }^{6}$ The Queen v. Akpan (1961) 1 All NLR 3

${ }^{7}$ See F.E. Eboibi, Cybercrime Prosecution and The Nigerian Evidence Act, 2011: Challenges of Electronic Evidence, 10 Nigerian Law and Practice Journal (2011) 139 - 160 \& F.E. Eboibi, Chapter 2 - Introduction to Law \& Cybercrime in F.E. Eboibi(ed), Handbook on Nigerian Cybercrime, Benin: Justice Jeco Printing \& Publishing Global, 2018, 223 - 245 for detail analysis

${ }^{8}$ (1969) NMLR 194.
} 
must not shut its eyes to the mysteries of computer. In modern times reproduction and inscriptions on ledgers or other documents by mechanical process are common place and section 37 cannot therefore only apply to books of accounts. ${ }^{1}$

Thirteen years later, precisely in 1976, the Nigerian Supreme Court in Yesufu v. $A C B^{2}$ stated thus: ...while we agree that for the purpose of Sections 96(1)(h) and 37 of the Act, "bankers books" and books of account" could include "ledgers cards", it would have been much better, particularly with respect to a statement of account contained in document produced by a computer, if the position is clarified beyond doubt by legislation as had been done in England in the Civil Evidence Act... ${ }^{3}$

The above pronouncements took a toll on lower courts in the sense that Courts that are not willing to admit digital evidence would place reliance on the case of Yesufu vs. $A C B^{4}$ and insist that the acceptance of digital evidence is not expressly stated in the Nigerian Evidence Act. On the other hand, Esso West Africa Inc. v. T. Oyegbola, ${ }^{5}$ gave the nod for the admissibility of digital evidence.

After that, Nigeria witnessed the development of computers and the availability of information and communication infrastructure. The deregulation of the telecommunication industry in the late 1990s signaled the increase of Internet Service Providers (ISPs) and Cybercafés in the country. Furthermore, the Nigerian Government in 2001 commissioned a body of experts to design a National Policy on Information Technology (NPFIT) ${ }^{6}$ which subsequently resulted in the enactment of the National Information Technology Development Agency (NITDA) Act 2007. The foregoing activated a robust availability of computer and mobile phone services, a liberalized telecommunications sector and internet service provision business. Youths were trained in IT skills, quite a number of unemployed and underemployed citizens became gainfully employed and self-employed in the ICT sector; and cybercafés sprung up in every part of the country. ${ }^{7}$ Consequently, Nigerians were now engaged in electronic commerce and contracts, online shopping, online banking platforms, online advertisement and marketing, e-mail and electronic communication, online research, online news and use of websites. Disputes that arose from these channels required legal framework to ensure the applicability of digital forensic evidence during courts proceedings. Nigerians consequently, clamored for a new law on electronic evidence. On 3 June 2011, former Nigeria's President, Dr. Goodluck Jonathan, signed into law a new Evidence Act. The 2011 Act substantially repealed the hitherto Evidence Act 1945 after more than 50years and added a number of new provisions. The 2011 Act allows the admissibility of digital forensic evidence in Nigerian courts. ${ }^{8}$

Section 67 of the Evidence Act 2011 negated the application of opinion evidence when it stated thus: "The opinion of any person as to the existence or non-existence of a fact in issue or relevant to the fact in issue is inadmissible except provided in ss. 68 to 76 of this Act." The basis for this exclusion is that opinion is a conclusion; hence, it is often irrelevant, unreliable, and logically worthless, and it tends to usurp the functions of the courts whose exclusive duty is to draw conclusions and inferences from the available evidence. However, the opinion of a digital forensic expert who appears in court to give digital forensic evidence is not regarded as an opinion by virtue of section 68 of the Nigerian Evidence Act 2011. Section 68 (1) provides that: "When the Court has to form an opinion on a point of law, customary law or custom, or of science or art, or as to identity of hand writing or conducting finger impressions, the opinions upon that point of persons specially skilled in such foreign law, customary law or custom, or science or art, or in questions as to identity of handwriting or finger impressions, are admissible." Furthermore, section 68(2) of the Nigerian Evidence Act 2011 expressly states who an expert is when it provides that: "Persons so especially skilled as mentioned in subsection (1) of this section are called experts."

The legal implication of section 68 is that digital forensic being 'the science of locating, extracting, and

\footnotetext{
Ibid at 216-217.

2 (1976) 1 All NLR (pt.1) 328

${ }^{3}$ Ibid at 524. Emphasis is mine.

${ }^{4}$ (1976) 1 All NLR (pt.1) 328; UBA vs. Sani Abacha Foundation for Peace and Unity(SAPFU) (2004) 3 NWLR (pt.861) 516; see also Numba Commercial Farms Ltd \& Anor vs. Nal Merchant Bank Ltd \& Anor (2001) 16 NWLR (pt. 740) 510.

5 (1969) NMLR 194; Trade Bank v.Chami (2003) 13 NWLR (pt.836) 158

${ }^{6}$ Ibid.

${ }^{7}$ See generally F.E. Eboibi, Chapter 2 - Introduction to Law \& Cybercrime in F.E. Eboibi(ed), Handbook on Nigerian Cybercrime, Benin: Justice Jeco Printing \& Publishing Global, 2018, 25-26; F.E Eboibi, 'Enforcement of Cybercrime in Nigeria: Are We Still Having Teething Problems?' Being a paper presented in a Certificate Training Course/Conference; Cybersecurity, Sovereingty, and Democratic Governance in Africa organized by the Council for the Development of Social Science in Africa, Democratic Governance Institute, Dakar, Senegal, 27 July 2015 - 7 August 2015, 1-2; see generally also F.E. Eboibi, 'A Review of the Legal and Regulatory Frameworks of Nigerian Cybercrimes Act 2015' (2017) 33 Computer Law \& Security Review, 700-703.

${ }^{8}$ F.E. Eboibi, Cybercrime Prosecution and The Nigerian Evidence Act, 2011: Challenges of Electronic Evidence, 10 Nigerian Law and Practice Journal (2011) 139- 160 \& F.E. Eboibi, Chapter 2 - Introduction to Law \& Cybercrime in F.E. Eboibi(ed), Handbook on Nigerian Cybercrime, Benin: Justice Jeco Printing \& Publishing Global, 2018, 223 - 245
} 
analyzing types of data from different devices, which specialists then interpret to serve as legal evidence" ${ }^{1}$ is acceptable in the Nigerian Courts and not regarded as opinion evidence. It means that digital forensic evidence emanating from handwriting, computer, DNA, mobile phone, fingerprints analysis sought to be presented in court by digital forensic experts are allowed. Although there is no specific legal framework on digital forensic in Nigeria, the practice of digital forensics has been given the force of law by section 68 of the Nigerian Evidence Act 2011.

Moreover, section 258 of the Nigerian Evidence Act $2011^{2}$ definition of documents to include electronic documents and devices and section 84 of the Nigerian Evidence Act $2011^{3}$ allowing the admissibility of digital evidence gives a further boost to the practice of digital forensic and the acceptability of digital forensic evidence in Nigerian Courts. Again, the recent enactment of the Nigerian Cybercrimes Act 2015 which provides for cybercrime offences in Part III of the Act shows the necessity of digital forensic evidence because digital information is often relevant in proving or disproving a fact or point in question relating to the guilt or innocence of a cybercrime perpetrator. As such, the information forms part of the totality of the evidence before the Court. ${ }^{4}$ The Nigerian Administration of Criminal Justice Act 2015 gives another boost to the application of digital forensics evidence in the sense that it has curtailed the extraction of confessional statements from suspects by law enforcement agents. ${ }^{5}$ Hence, law enforcement agents by necessary implication will have to resort to digital forensics investigation in order to identify and prosecute perpetrators of crimes in the Nigerian polity. Bringing

\section{${ }^{1}$ Ibid.}

${ }^{2}$ Section 258(d) provides: "document" includes (a) books. maps, plans, graphs. drawings, photographs, and also includes any matter expressed or described upon any substance by means of letters, figures or marks or by more than one of these means, intended to be used or which may be used for the purpose of recording that matter;

(b) any disc. tape, sound track or other device in which sounds or other data (not being visual images) are embodied so as to be capable (with or without the aid of some other equipment) of being reproduced from it, and (c) any film, negative, tape or other device in which one or more visual Images are embodied so as to be capable (with or without the aid of some other equipment) of being reproduced from it; and

(e) any device by means of which information is recorded. stored or retrievable including computer output.

${ }^{3}$ Section 84 . (1) In any proceeding a statement contained in a document produced by a computer shall be admissible as evidence of any fact stated in it of which direct oral evidence would be admissible. if it is shown that the conditions in subsection (2) of this section are satisfied in relation to the statement and computer in question.

(2) The conditions referred to in subsection (1) of this section are

(a) that the document containing the statement was produced by the computer during a period over which the computer was used regularly lo store or process information for the purposes of any activities regularly carried on over that period, whether for profit or not by anybody, whether corporate or not, or by any individual;

(b) that over that period there was regularly supplied to the computer in the ordinary course of those activities information of the kind contained in the statement or of the kind from which the information so contained is derived;

(c) that throughout the material part of that period the computer was operating properly or, if not, that in any respect in which it was not operating properly or, if not, it was out of operation during that part of that period was not such as to affect the production of the document or the accuracy of its contents; and

(d) that the information contained in the statement reproduces or is derived from information supplied to the computer in the ordinary course of those activities.

(3) Where over a period the function of storing or processing information for the purposes of any activities regularly carried on over that period as mentioned in subsection (2) (a) of this section was regularly performed by computers, whether-

(a) by a combination of computers operating over that period;

(b) by different computers operating in succession over that period:

(c) by different combinations of computers operating in succession over that period; or

(d) in any other manner involving the successive operation over that period in whatever order of one or more computers and one or more combinations of" computers.

all the computers used for that purpose during that period shall be treated for the purposes of this section as constituting a single computer; and references in this section to a computer shall be construed accordingly.

(4) In any proceeding where it is desired to give a statement in evidence by virtue of this section. a certificate -

(a) identifying the document containing the statement and describing the manner in which it was produced;

(b) giving such particulars of any device involved in the production of that document $\mathrm{a}^{\prime}>$ may be appropriate for the purpose of showing that the document was produced by a computer:

(b) dealing with any of the matters to which the conditions mentioned in subsection (2) above relate, and purporting to be signed by a person occupying a responsible position in relation to the operation of the relevant device or the management of the relevant activities, as the case may be. shall be evidence of the matter stated in the certificate: and for the purpose of this subsection it shall be sufficient for a matter to be stated to the best of the knowledge and belief of the person stating it.

(5) For the purposes of this section

(a) information shall be taken to be supplied to a computer if it is supplied to it in any appropriate form and whether it is supplied directly or (with or without human intervention) by means of any appropriate equipment:

(b) where, in the course or activities carried on by any individual or body, information is supplied with a view to its being stored or processed for the purposes of those activities by a computer operated otherwise than in the course of those activities, that information, if duly supplied to that computer, shall be taken to be supplied to it in the course of those activities;

(e) a document shall be taken to have been produced by a computer whether it was produced by it directly or (with or without human intervention) by means of any appropriate equipment.

${ }^{4}$ F.E. Eboibi, Cybercrime Prosecution and The Nigerian Evidence Act, 2011: Challenges of Electronic Evidence, 10 Nigerian Law and Practice Journal (2011) 139 - 160 \& F.E. Eboibi, Chapter 2 - Introduction to Law \& Cybercrime in F.E. Eboibi(ed), Handbook on Nigerian Cybercrime, Benin: Justice Jeco Printing \& Publishing Global, 2018, 223 - 245

${ }^{5}$ Administration of Criminal Justice Act 2015, ss. 15(4) \& 17(1) \&(2); Nwakuche Jerry Nnjiofor v, The Federal Republic of Nigeria(2018)

LPELR - 43925 
recovered digital evidence requires the ingenuity of digital forensics experts.

\section{Judicial application of digital forensics evidence in Nigerian Courts}

This section examines the various digital forensic evidence that is the subject of digital forensic examination, and, how different Courts in Nigeria have applied the same in the dispensation of justice.

\subsection{Computer and Mobile or Cell Phone forensic evidence}

Mobile or cell phone forensic is a task carried out by a mobile or cell phone forensic expert by extracting and analyzing information or data stored in mobile or cell phone devices. ${ }^{1}$ Ultimately most owners of computer and mobile devices use them positively to track their health, socialize, start their car, monitor their in-home surveillance cameras, bank, communicate and shop. ${ }^{2}$ Consequently, the device houses much information inside it. From another perspective, most crimes being committed today, mobile devices, and computers are used as instruments. ${ }^{3}$ Upon analysis of computers and mobile phones, digital forensic evidence recovered from such computers and phones are presented before the Court to aid the dispensation of justice.

In Federal Republic of Nigeria v. Dr Joseph Nwobike $(S A N),{ }^{4}$ the defendant was arraigned on a $3^{\text {rd }}$ Amended Information dated 27 December 2017 on a total of 18 count charge involving a two(2) count charge of offering gratification to a public official contrary to section 64(1) of the Criminal Law of Lagos State No. 11, 2011, a fifteen count charge of attempting to pervert the course of justice contrary to section 97(3) of the Criminal Law of Lagos State No. 11, 2011, and a one(1) count charge of making false information to an officer of the Economic and Financial Crimes Commission(EFCC) contrary to section 39(2) of the Economic and Financial Crimes Commission (Establishment) Act 2004. In proof of the charge, the prosecution relied on digital forensic evidence. The EFCC seized the defendant's Samsung Galaxy Note 4 phone and sent the same to their forensic department for analysis and extracted and published the contents, the defendant's private and confidential text messages. The Court admitted in evidence the defendant's Samsung Galaxy Note 4 phone - Exhibit P18, the ownership attestation form for the defendant's Samsung Galaxy Note 4 phone - Exhibit 19, the analysis report of the defendant's Samsung Galaxy Note 4 phone - Exhibit P20, the compact disc being the analysis report of the defendant's Samsung Galaxy Note 4 phone and the extracts/print out of compact disc- text messages from the defendant's Samsung Galaxy Note 4 phone - Exhibit 22. In finding the defendant guilty of attempting to pervert the course of justice by sending text messages to one Mr. Jide of the Federal High Court stating the names of the Hon. Judges to which matters filed by him should be assigned, the court placed reliance on the mobile or phone forensic evidence (Exhibits 18, 19, 20, $21 \&$ 22). The evidence was tendered through one Ogbole Alex (PW6), EFCC Operative from the Forensic Unit, a certified access data examiner, and PW7, Danladi Daniel, EFCC investigator. The PW7 sought the order of the Court to play the content of Exhibit 21 openly before the Court, which was eventually granted without opposition from the defendant. The contents were projected on a screen provided by PW7, and over 14,317 SMS were found in Exhibit 22. The text messages showed that the defendant paid money to several judges and was in constant communication with the officers of the Federal High Court, including Mr. Jide. The defendant was, however, not found guilty of counts $1,2,4,5,6$, and 18 and consequently discharged and acquitted of the said counts. In respect to counts $3,7,8,9,10,11,12,13,14,15,16$ and 17 , the defendant was guilty and convicted for attempting to pervert the course of justice and sentenced to a term of one month, 30 days imprisonment.

A fundamental issue that arose about the digital forensic evidence admitted in course of the proceedings is whether or not the EFCC officials obtained the defendant telephone, Samsung Galaxy Note 4 in contravention of the law and thereby entitled the evidence from it to be expunged from the records of the Court. It is evident from the facts of the case that the defendant's mobile phone was seized from him when he was invited to the EFFC's Office. Without an order of a competent Court, the EFFC operatives sent the defendant's mobile phone to their forensic department for analysis and extraction and published the contents, the defendant's private and confidential text messages, in breach of the defendant's rights to privacy guaranteed under section 37 of the Constitution of the Federal Republic of Nigeria, 1999(as amended). Based on the actions of the EFCC operatives the defendant requested the Court in his final address to expunge the digital forensic evidence having been improperly obtained pursuant to section 15 of the Nigerian Evidence Act 2015. Although the Court agreed that the digital forensic evidence were improperly obtained, it refused to expunge them on the ground that the desirability of admitting them outweighs the undesirability pursuant to section 14 of the Nigerian Evidence Act 2011. The objection of the

\footnotetext{
${ }^{1}$ Daniel Ogden, 'Mobile Device Forensics: Beyond Call Logs and Text Messages' (2017) 65 United States Attorneys' Bulletin, 11; Andrew McQuilkin, 'Sleeping Gate-Keepers: Challenging the Admissibility of Cell Phone Forensic Evidence Under Daubert' (2011) 11 Journal of High Technology Law, 365, 372(" Since modern cell phones are essentially small, low powered computers, the study of mobile phone forensics emerged as a branch of computer forensics.")

${ }^{2}$ Ibid.

${ }^{3}$ Ibid.

${ }^{4}$ Unreported, Suit No: LD/2516C/16. Judgment delivered by Hon. Justice R.I.B Adebiyi of the High Court of Lagos State, Ikeja Judicial Division, Holden at Ikeja on 30 April 2018
} 
defendant was consequently dismissed.

The judgment of the court refusing to expunge the evidence despite the overwhelming evidence of the illegality of the way and manner the EFFC operatives obtained the evidence is appalling. It has sent a positive message to the EFCC operatives to continue in their illegality and trampling on the fundamental rights of innocent Nigerians. This would have been an opportunity for the judiciary to curtail the excesses of the EFCC during investigations. Collecting the mobile phone of a person and examining his private communication in the guise of conducting an investigation is the height of illegality.

In Jude Onwuzulike v. The State, ${ }^{1}$ the appellant was arraigned before the High Court of Justice of Anambra State of Nigeria, holden at Otuocha in Anambra Judicial Division before G.C. Anulude, J., on a charge of kidnapping contrary to Section 315(2)(a) of the Criminal Code, Anambra State (Amendment) Law, 2009. In the course of the proceedings, the charge was, however, amended to read Section 315(1)(b) of the Criminal Code. The appellant pleaded not guilty to the amended charge. The appellant was found guilty and sentenced to life imprisonment without an option of fine on 16 June 2014. Dissatisfied with the judgment, the appellant appealed before the Court of Appeal, Enugu, which affirmed the decision of the trial court and dismissed the appellant's appeal. In arriving at the judgment, the court relied on the digital forensic evidence of PW6, Fred Nwachukwu, from the State Security Service, a mobile forensic expert. In the course of investigating the disappearance of one Chinwuba Ekwenze, deceased, he wrote to MTN (telecommunication company) to request for the deceased call history records. Through the computer-generated evidence that recorded the conversations between the appellant and the deceased and call flash that was put in evidence. Detailed evidence was given as to how the prosecution witness was able to link the appellant with the disappearance of the deceased. The call data from MTN was admitted and marked Exhibit B and the flash drive from the computer, Exhibit C.

\subsection{Fingerprint forensic evidence}

Fingerprint forensic expert is also known as latent print examiners. Based on their extraordinary knowledge, fingerprints recovered from a crime scene or on the instrument used in perpetrating crime is analyzed to detect, identify, and link the perpetrator of the crime. ${ }^{2}$ The result of the analysis carried out forms part of the fingerprint forensic evidence presented in court in the administration justice.

In Feyisayo Alatise v. The State, ${ }^{3}$ the appellant and two others were arraigned before the High court of Ondo State sitting at Akure on a two-count charge of conspiracy to commit murder contrary to and punishable under Section 324 of the Criminal Code, Cap. 30 Vol, II Laws of Ondo State of Nigeria, 1978 and murder Contrary to Section 316 (1) and punishable under Section 319 (1) of the Criminal Code, Cap, 30 Vol. II Laws of Ondo State of Nigeria, 1978. The accused persons were convicted and sentenced to 14 years imprisonment with hard labour on the first count and death by hanging on the second count by the trial Court. Dissatisfied with the judgment, they jointly filed an appeal before the Court of Appeal, Akure. One of the issues that arose on appeal was a determination as to whether Exhibit "B" (locally made gun) was the gun that killed the deceased. Although there was evidence before the Court that the PW4 took the appellant's fingerprint and put a copy in the file at the State C.I.D. office. No effort was made to link the fingerprint with Exhibit B. There was no report by a forensic expert to confirm that it was the appellant who pulled the trigger of Exhibit B, especially when the identity of the person who pulled the trigger is unknown. Consequently, the judgment of the trial Court convicting the appellant of conspiracy to commit murder and murder and sentencing him to 14 years imprisonment and death by hanging respectively was set aside. The appellant was accordingly discharged and acquitted.

However, the Supreme Court dispensed with a piece of fingerprint evidence where there was other available evidence to determine the guilt of the defendant. In James Chiokwe v. The

State, ${ }^{4}$ the appellant appealed against the judgment of the Court of Appeal that convicted and sentenced him for the offence of murder contrary to Section 316 (1) and punishable under Section 319 (1) of the Criminal Code, Cap 30 Vol.2, Laws of Eastern Nigeria, 1963. At the trial Court, the appellant was alleged to have murdered one Dorothy Ibekwe, a 15-year-old secondary school girl on or about 5 March 1983 at Ugbo Edem Nike in the Enugu Judicial Division with a matchet (Exhibit C). The said Dorothy had been raped and murdered. The trial Court convicted the appellant for murder and sentenced him to death. On further appeal to the Court of Appeal, Enugu, it was dismissed. One of the issues was whether Exhibit $\mathrm{C}$ was the weapon with which the deceased was killed. From the evidence before the Court, there was no expert evidence that Exhibit $\mathrm{C}$ had the fingerprint impression of the appellant before the same was admitted in evidence as corroborative of the guilt of the appellant. The Supreme

${ }^{1}$ (2017) LPELR-41889(CA)

2 John W Bond, 'The Value of Fingerprint Evidence in Detecting Crime' (2009) 11 International Journal of Police Science Management, 77 ("In the UK, fingerprints recovered from a crime scene2 are searched against fingerprints of known offenders and, if a match (known as a fingerprint identification) is made, then that information is passed to investigating police officers. This usually leads to the arrest of the individual (who would be considered a suspect for the crime) and a police interview follows in which the suspect is expected to account for how his or her fingerprints came to be")

3 (2012) LPELR-9469(CA)

${ }^{4}$ (2012) LPELR-19716(SC) 
Court stated thus:

The Appellant's counsel asking for finger prints of the Appellant on the weapon before it can be accepted or that no forensic examination thereof before the weapon can be taken as the instrument of death, is an elegant argument which is bereft of other factors that could demolish such an argument like the cogent, compelling and direct circumstances which lead to no other explanation than that Exhibit " $\mathrm{C}$ " is the instrument deployed in taking the life of the deceased and an act effected by the Appellant... Therefore, when the court can infer from the circumstances available and established other facts which point to no other hypothesis or reasoning than the guilt of the accused then absence of forensic blood test of the deceased on the instrument or the fingerprint of the Accused/Appellant as in this case on that weapon becomes moot. $^{1}$

\subsection{Handwriting forensic evidence}

Handwriting forensic is the identification of authors' disputed writings. ${ }^{2}$ Handwriting forensic experts are called in the course of proceedings to testify in court to present handwriting forensic evidence to determine whether a particular person is the author of writing or lines of writing.

In Bolanle Abeke v. The State, ${ }^{3}$ The appellant, Bolanle Abeke, was charged on information before the Abeokuta High Court of Ogun State for an offence under Section 1 (1)(b) of the Dishonoured Cheques (Offences) Act No.44 of 1977. The appellant was alleged to have obtained a credit of N3,300.00 (three thousand, three hundred Naira) from one Ganiyu Ajayi through Cheque No. UDB 130480, Nigeria-Arab Bank Nigeria Ltd., Odeda and, upon presentation of the said cheque on the particular date, the cheque was dishonoured on the ground of insufficient funds in the appellant's account to take care of the value of the cheque. The appellant was found guilty and sentenced to a two-year term of imprisonment. Aggrieved by the conviction, the appellant appealed before the Court of Appeal, Ibadan, and the appeal was dismissed in a unanimous decision and affirmed the conviction and sentence given by the trial Court. Aggrieved further, the appellant brought an appeal before the Supreme Court. The Supreme Court, in a considered judgment, dismissed the appellant's appeal and further affirmed the appellant's conviction and sentence. In arriving at her judgment, the Supreme Court took into consideration the handwriting forensic evidence given by the Prosecution Witness 4(PW4), a handwriting analyst, to the effect that "upon a comparison of the specimen signature of the appellant with the signature on the cheque leaf exhibit ' $\mathrm{B}$ ' stated that exhibit ' $\mathrm{B}$ ' in fact bore the signature of the appellant."

This is despite the appellant's testimony in defence denying issuing and signing the specimen cheque, exhibit 'B' on the ground that she lost her cheque book sometime in 1981 and reported the loss to the bank in writing sometime in 1982. The Supreme Court, however, disbelieved this piece of evidence. The PW4, handwriting forensic expert, noted in his evidence available before the Court, thus:

I took exhibit B to the laboratory where I examined the signature therein with the aid of a video spectra comparator. The examination revealed evidence of natural execution devoid of simulation of a known model signature. On comparison with the signature with exhibits A and D-D5 1 found them characteristically identical. I equally carried out a comparison of the handwriting on exhibit $\mathrm{B}$ with the specimen on exhibit $\mathrm{C}-\mathrm{C} 5$ and found features of similarity peculiar to one writer, i.e. the writer of exhibit $\mathrm{C}$ to $\mathrm{C} 5$ wrote the handwriting contained in exhibit B. ${ }^{5}$

Based on the above handwriting forensic evidence, the Court concluded:

There is evidence before me that the accused signed exhibit B. P.W4 testified here as having examined exhibit $\mathrm{B}$, he compared the signature thereon with the handwriting and signature on exhibit $\mathrm{A}$ (letter of apology handwritten by the accused to P.W.2) as well as exhibits D - D5 with comparative table shown on exhibit $\mathrm{E}$ which vividly revealed features of similarity and came to the conclusion that the writer of exhibit A (i.e. the accused is the same as the writer of exhibits D - $\quad$ D5 as well as the signature on exhibit B (the offending cheque) which he said was even obvious to alay man to see and compare. I believe the evidence of PW.4. He has done a good job and the explanation even under devastating cross examination was clear and straight forward maintaining a steady stand and unshaken...It is noted that this P.W.4 - the expert was not contradicted, and was not cross-examined as to the accused not signing exhibit $\mathrm{B}$, and to me his credibility remains untainted due to failure to elicit any evidence adverse to the opinion of P.W.4, which is a basis to believe the said PW.4. ${ }^{6}$

In another development, despite the presence of handwriting forensic evidence by a handwriting forensic

\footnotetext{
${ }^{1}$ Ibid at 23 .

${ }^{2}$ Andre A Moenssens, 'Handwriting Identification Evidence in the Post-Daubert World' (1997) 66 UMKC Law Review, 251, 256

3 (2007) LPELR-31(SC)

${ }^{4}$ Ibid.

${ }^{5}$ Ibid.

${ }^{6}$ Ibid.
} 
expert who examined the letters which were the basis of a forgery charge, the Court dispensed with the same on the ground that the Prosecution was not bound to call an expert. The attitude of the Court of Appeal is inexplicable, considering the precedent laid down by the Supreme Court in the above case. In Yohanna Dalyop v. The State, ${ }^{1}$ the Appellant amongst others was arraigned before the High Court of Justice Plateau State on four counts based on an Amended charge for forgery. The allegation was that the appellant forged a letterhead of Cotton and Agricultural Processors Ltd. to show that an offer of fifty million naira (N50, 000,000.00) was made, that an original offer of forty million (N40, 000,000.000) did not include houses on the premises of Kuru Ginnery and that the house had been offered to him at forty-six million (N46, 000,000.000) and other letters addressed to his company acknowledging the receipt of ten million naira N10, 000,000.000) and forty six million (N46, 000,000.000) for the houses with the intention to cause Plateau Investment and Property Development Ltd. to part with ten million naira $(\mathrm{N} 10,000,000.000)$ and forty six million naira $(\mathrm{N} 46,000,000.000)$ respectively. The appellant was found guilty of the offence of forgery contrary to section 364 of the Penal code on the two counts charge and sentenced to two years imprisonment or N10, 000,00 (Ten Thousand) Naira in the alternative in each of the counts and to run concurrently. Dissatisfied with the judgment, the appellant appealed before the Court of Appeal.

One of the issues on appeal was whether it was right for the trial Court to ignore the handwriting forensic evidence given by the Forensic Expert (DW1) called by the appellant when there was no contrary evidence of any Forensic Expert from the prosecution as to how the appellant made the forged letters. Although the Prosecution contended that handwriting or signature was not an issue in the case, the Court's conclusion on the issue was not substantiated when it stated thus:

On the contention that the prosecution ought to have called a forensic expert to examine Exhibit 2 and 3 to determine whether Appellant actually forged the letters dated 22nd September, 2000attached to Exhibit 1 and letter dated 11th December, 2001 Exhibit 2. This complaint by the Appellant is unfounded. This is because it is not for an Accused person to tell the Respondent how it will go about the prosecution. ${ }^{2}$

The Court did not ascertain the implication of the only handwriting forensic evidence before the Court. Did the Court believe or disbelieve the evidence of the forensic expert in the absence of any other forensic evidence? How did the Court find that the letters were actually forged? Was there other evidence superior to the forensic expert evidence? These are questions begging for answers that the Court did not advert her mind.

\subsection{DNA forensic evidence}

DNA forensic is the application of DNA technology to biological specimens of individuals. To aid the identification of persons who are involved in crimes. Also, where there is a dispute as to the identity of a person. It is a tool applied by most law enforcement agents in resolving sex offences and violent crimes. ${ }^{3}$ The biological specimens used for DNA forensic include urine, blood, feces, tissue, cells, saliva semen, hair, bone, and teeth. Reports emanating from such DNA analysis are given as digital forensic evidence to assist courts in the determination of matters brought before them

In Shonubi v. People of Lagos State ${ }^{4}$ the appellant was arraigned before the High Court of Lagos State for a charge of murder contrary to section 316 of the Criminal Code Law of Lagos State, Cap C17, Vol. 12, 2003. The appellant was alleged to have been responsible for the death of one Miss Anniemeke Steen by strangulating her in a bathtub full of water. The deceased mother and her friend raised an alarm after they noticed the dead body upon their return from a shopping spree. Shell Nigeria Exploration Petroleum Company security personnel who were within the vicinity were consequently attracted and immediately searched the area where nine(9) suspects were arrested. DNA forensic examination was employed both in the United Kingdom and in Nigeria, and the appellant was linked to the death of the deceased. This prompted the arraignment of only the appellant in court. The trial Court found the appellant guilty and sentenced him to death based on the DNA forensic evidence provided by the Prosecution. Dissatisfied with the judgment, the appellant appealed to the Court of Appeal. Obaseki Adejumo JCA in dismissing the appeal held as follows:

Forensic report of PW6, exhibit E was tendered. He stated that of the three (3) questions I forensic analysis, two (2) were answered in Nigeria while the final question was sent to London. He said there was a stain on the shirt of the defendant, it was subjected to three (3) stages of test he said:

i. Was the stain blood?

ii. Does this blood belong to a human being?

iii. Does the human blood belong to the deceased?

And it was this question 1 and 2 that were answered in Nigeria and that the answer sent

\footnotetext{
1 (2013) LPELR-21898(CA)

${ }^{2}$ Ibid at 36.

${ }^{3}$ Jay V Miller, 'The FBI's Forensic DNA Analysis Program' (1991) 60 FBI Law Enforcement Bulletin,11; David H Kaye, 'Trawling DNA

Databases for Partial Matches: What is the FBI Afraid of (2009) 19 Cornell Journal of Law and Public Policy, 145

${ }^{4}$ Shonubi v. People of Lagos State (2015) All FWLR (pt. 801) at 1424, 1432 to1433
} 
confirmed that the stain on the shirt was blood which matched that of the deceased. He further added that the evidence of the PW6 to the effect that the DNA analysis of the blood stain found on the checkered shirt of the appellant matched that of the appellant was positive identification of the appellant's culpability as the person that caused the death of the deceased. ${ }^{1}$

In a similar case where DNA forensic evidence was not presented before the Court, despite the trial Court and Court of Appeal conviction of the defendant, it was set aside, and the defendant discharged and acquitted by the Supreme Court of Nigeria. ${ }^{2}$ In Ogwa Nweke Onah v. The State, ${ }^{3}$ the issue for determination before the Nigerian Supreme Court was whether in the absence of DNA forensic evidence showing that the bloodstain on the matchet and the wrapper (exhibit A and $\mathrm{C}$ respectively) can be said to be that of the deceased or linked to the appellant to warrant holding the appellant guilty by both the trial Court and Court of Appeal. UWAIS, J.S.C. (AHTW) (Delivering the Leading Judgment) in discharging and acquitting the appellant stated thus:

...there is no proof that the stains were human blood. Even if there is such proof, there was no evidence to show that the bloodstains belong to the same blood group as that of the deceased. All these go to show how weak and inconclusive the prosecution's case had been. In my opinion, therefore, both the trial court and the Court of Appeal were in serious error in holding that there was sufficient circumstantial evidence on which the appellant could have been properly found guilty as charged. On this ground alone the appeal succeeds. ${ }^{4}$

According to KAZEEM JSC(AHTW):

All that the prosecution succeeded in proving, were that certain blood stains which were thought to be human blood by prosecution witnesses, were found on the corpse of the deceased behind the house where the Appellant lived with her husband, (P.W.1); that those stains were also found on a matchet - Exh. A which was found in the same house; and on the wrapper worn by the Appellant (Exh. C) on that day. No attempt was made to send samples of those blood stains for laboratory analysis in order to determine whether or not the stains were human blood. There was even no comparison made between the deceased's blood and the blood stains on which the prosecution relied... Indeed when the police witness (P.W.4) who investigated the case, was being cross examined he said:

"Q: You collected Exhs. A \& C. You cannot say whether it was human blood?

A: I cannot say.

Q: You did not send these exhibits to the Forensic Laboratory in Lagos?

A: I did not."

It is therefore clear from those answers that this vital witness for the prosecution was not sure that the blood stain was human blood. Wherein then lies the nexus between the deceased and the Appellant as the only person who could have killed the deceased ${ }^{5}$

OPUTA JSC (AHTW) on his own part stated thus:

To link these blood stains found in the compound, and the blood stains found on the matchet with the blood of the deceased, and then ultimately, with her murderer, there ought to be evidence to show that those strains (around the compound and on the matchet) were human blood stains of the same blood type and grouping as that of the deceased. But the police Sergeant Franklin 1rozuru called as 4th P.W. who testified to these blood stains admitted in cross-examination that he could not say whether the stains he saw were human blood stains. He did not collect specimens of the stains around the compound. He did not send the matchet and specimen stains to the Forensic Laboratory for necessary analysis and comparison. Talking about blood stains, there was evidence that some stains presumably blood stains were found on a wrapper worn by the Appellant. That wrapper was not sent for analysis and there was therefore no nexus between the blood stains found on the wrapper of the Appellant and human blood let alone the blood of the deceased. This ought to have been established by positive evidence. There is no evidence to show that the "blood" stains found on the wrapper worn by the Appellant was not only human blood but also human blood of the deceased that is blood of the same type and grouping as that of the deceased. Again, the matchet was not examined for finger prints and so here too there was no nexus between the Appellant and the matchet $^{6}$

\footnotetext{
Ibid.

${ }^{2}$ Ogwa Nweke Onah v. The State(1985) LPELR-2668(SC) - The appellant was tried and convicted of murder by the Anambra State High Court, sitting at Abakaliki. Only the prosecution adduced evidence at the trial. The learned judge believed the testimony of the prosecution witnesses. On appeal to the Court of Appeal, the decision of the trial court was upheld, and the appeal dismissed. The accused appealed further to the Supreme Court.

3 (1985) LPELR-2668(SC

${ }^{4}$ Ibid at 3-11.

${ }^{5}$ Ibid. at $16-18$

${ }^{6}$ Ibid at $21-22$.
} 


\subsection{Ballistic forensic evidence}

Ballistic forensic is the art of examining "evidence relating to firearms at a crime scene, including the effects and behaviour of projectiles and explosive devices." In this sense, what the Ballistic forensic expert does is matching bullets, fragments, and other available evidence with recovered weapons of suspected perpetrators of crime or those that are a party to a dispute. ${ }^{2}$ It is also the "science of identifying the particular gun that a recovered bullet or cartridge case came from. ${ }^{3}$ Ballistic forensic experts may be required to give evidence based on their findings in civil or criminal matters.

In Mohammed Auwal \& Ors. v. The Federal Republic of Nigeria ${ }^{4}$ the appellants amongst other counts and offences were charged before the Federal High Court for Illegal possession of locally made guns (one gun each, totaling seven guns) without a valid license contrary to S. 5(1) of the Firearms Act Cap. F28, Laws of the Federation of Nigeria 2004 and punishable under S.27(1)(c) (i) of the same Act. They were found guilty, convicted, and sentenced to various terms of imprisonment by the trial Court. Dissatisfied with the judgment, they appealed to the Court of Appeal. In affirming the judgment of the trial Court, the Court of Appeal took into consideration the ballistic report (Exhibit 'B') that were admitted through PW1, Mulenga Mwatunwa, without objection. The ballistic report of the Dane guns and shotguns revealed residue of burnt propellants, which was an indication that the guns were recently fired and the fact that the weapons were firearms that were recently used. Moreover, that the guns were loaded.

The importance of ballistic forensic evidence cannot be overestimated in the course of criminal trials when the issue of gun or firearm is directly involved in perpetrating the crime. A lack of forensic evidence may lead to the discharge and acquittal of the defendant. In Sampson Idowu v. The State, ${ }^{5}$ the appellant, Sampson Idowu, and two others were arraigned before the Ogun State High Court for conspiracy and armed robbery. They robbed one Simiat Sowunmi of Jewellery and the sum of N6,000 and John Adole of the sum of N2,000 while armed with a gun at Kemta Housing Estate Idi-Aba, Abeokuta and other persons.

The learned trial judge found the appellant guilty of conspiracy to commit armed robbery under Section 1(2)(a) of the Robbery and Firearms (Special Provisions) Act, Cap 398 Laws of the Federation of Nigeria, 1990 as amended by the Tribunals (Certain Consequential Amendments) etc Act, 1999, and armed robbery under Section 1(2)(a) of the Robbery and Firearms (Special Provisions) Act Cap. 398 Laws of the Federation of Nigeria, 1990 as amended by the Tribunals (Certain Consequential Amendments) etc Act, 1999 and sentenced him to death by firing squad. Dissatisfied with the judgment, the appellant appealed to the Court of Appeal, Ibadan. The Court of Appeal noted that the appellant made a confessional statement, but there was no corroborative evidence to justify the statement. The Court stressed the fact that the appellant was alleged to have been armed with a gun. No evidence to link the appellant with the gun. Again, empty cartridges were found at the scene of the crime. There was no explanation of which scene of the crime was being referred to. There was no ballistic report to show the type of gun that was fired; neither was the cartridge subjected to ballistic forensic. Consequently, the conviction and sentence of the appellant were set aside, and the appellant was discharged and acquitted.

\section{Judicial approach to digital forensic evidence}

This section examines the attitude of Nigerian Courts towards digital forensic experts and the nature of the evidence they give before the Courts. It notes that it is not in every proceeding that the assistance of a forensic expert is required. In circumstances where the Court is desirous of forensic expert evidence, the competence of the expert may determine the acceptability of the expert opinion rendered before the Court. In this regard, who does the Nigerian Court regarded as a competent forensic expert capable of giving expert evidence, and how does the court determine that? Realizing the importance of digital forensic evidence and the professional knowledge possess by forensic experts, it might be assumed that their opinion before the Court is final and the Court is bound to accept whatever they say. The approach of the Nigerian Courts in this respect forms part of the discussion in this subhead.

Moreover, there are always two parties in litigation, whether civil or criminal proceedings. For civil Claimant and defendant while criminal, Prosecution, and defence/defendant. It might be necessary for both parties in a litigation to request the services of a digital forensic expert to give evidence in support of their case. The dilemma here is the possibility of conflict in digital forensic evidence provided. In essence, how should a Nigerian Judge or magistrate solve such eventualities? The Court's knowledge of forensic is arguably limited to whatever

\footnotetext{
${ }^{1}$ Criminal Justice Degree Schools, Forensic Ballistics Expert: Career Guide, available at Last accessed 18 November 2019.

${ }^{2}$ Ibid.

${ }^{3}$ Andrew McQuilkin, 'Sleeping Gate-Keepers: Challenging the Admissibility of Cell Phone Forensic Evidence Under Daubert' (2011) 11 Journal of High Technology Law, 365 at 390-391 ("It is based on the principle that no firearm is built exactly the same, and therefore, its unique imperfections will leave different marks on the ammunition and casings when fired. The forensic examiner fires the suspect weapon and then compares the spent bullet and cartridge case with those found at the crime scene.192 He must then determine if there is a match based on his experience in the field")

${ }^{4}$ (2013) LPELR-20776(CA)

5 (2014) LPELR-22931(CA)
} 
the forensic expert informs the Court, whether the Court can reject such evidence and in what circumstance is germane. Most forensic experts are in the habit of displaying their findings electronically before Courts, what is the approach of Nigerian Courts?

\subsection{Competence of forensic expert}

Generally, an expert is someone especially skilled in any of the fields of foreign law, native law, and custom, or of science or act, or in identifying handwriting or finger impression or any of the aspects of forensic discussed above. ${ }^{1}$ It implies that a forensic expert that is capable of giving digital forensic evidence must be a witness that is equipped with knowledge that is beyond that of an ordinary layperson concerning the issue that requires expertise to understand. There is no specific law in Nigeria that lays down how a forensic expert skill is determined. However, for the Court to accept the digital forensic evidence or expert opinion, the expert must lay a foundation arguably through the expert's presentation of his credentials and experience that qualifies him/her as an expert. Several factors have been listed that an expert must show for the Court to believe the competence of the expert. They include, amongst others: the experience of the expert, educational qualifications, certifications, peer recognition, training, and awards. ${ }^{2}$

For instance, in United Bank for Africa Plc v. Patkan Ventures Limited, ${ }^{3}$ the Nigerian Court of Appeal stated thus: Experts are qualified according to a number of factors, including but not limited to, the number of years they have practiced in their respective field, works, certifications, licensing training, education, awards, and peer recognition. They may be called upon as consultants to a case and also used to give testimony at trial. Once listed as a witness for trial, the materials they rely upon in forming an opinion in the case is subject to discovery by the opposing parties. Experts in a wide variety of backgrounds may testify, such as construction, forensics, gemstones, and many more areas. They are allowed to be compensated for their time and expenses in preparing for and giving testimony, as long as they are not being paid to perjure themselves. ${ }^{4}$

The Court stated further that "in certain cases, the evidence of opinion of an expert is relevant, but he must be called as a witness. He must also state his qualification and satisfy the Court that he is an expert on the subject in which he is to give his opinion and he must state clearly the reasons for his opinion." In the absence of evidence of a proper foundation of an expert's skill and experience before the Court, the Court is bound to reject the digital forensic evidence. For instance, in Harrison Odiawa v. Federal Republic of Nigeria, ${ }^{5}$ the evidence of one of the two handwriting forensic experts was rejected on the ground that he failed to give an account of his skill and experience in the analysis of documents and handwriting. The Court noted: "PW5 started by giving his professional exposure and length of experience on the job while DW1 did not avail the Court of any such information about himself. While PW5 ably demonstrated his skill and explained to the Court how he arrived at his conclusion, it was apparent from the testimony of DW1 that all he went out for was to achieve a preconceived agenda to mislead the Court..."

\subsection{Usurping the powers of a Judge or Judicial officer}

It must be noted that the essence of calling a digital forensic expert or relying on forensic evidence in any trial is to assist the Court or presiding judicial officers in reaching its/her opinion concerning matters relating to the fields of science, art, custom, foreign Law and identity of handwriting etc. ${ }^{6}$ Consequently, it is a mere expert opinion that does not require the forensic expert to insist on the Court's acceptability of the same or that the forensic evidence is final. That will mean usurping the powers of the Court or the presiding judicial officer. The Court is at liberty to accept the opinion or reject it based on his/her discretionary powers. The case of Harrison Odiawa $v$. Federal Republic of Nigeria, ${ }^{7}$ is apt in this regard when the court held that: "...it follows therefore that the two witnesses called as handwriting experts in the present case were required not only to give result of their conclusion on the disputed documents but also to give some practical analysis in support of their reports in order to assist the trial judge in forming his own opinion on the disputed documents. The ultimate acceptance or reliance of the report of an expert remains under the discretion of the trial judge who under the circumstances of the case may even decide to reject it." In the case of Attorney-General of Oyo State \& Anor v. Fairlakes Hotels Limited \& Anor (No. 2), ${ }^{8}$ My Lord UWAIS, J.S.C (AHTW) stated that: "It therefore follows that it is not sufficient to say that where a document written by an expert is tendered in evidence and that document or the testimony through which it is

\footnotetext{
${ }^{1}$ Nigerian Evidence Act, 2011, s.68(1) \&(2)

2 (2017) LPELR-42392(CA)

${ }^{3}$ Ibid.

${ }^{4}$ Ibid.

5 (2008) LPELR-4230(CA)

${ }^{6}$ Nigerian Evidence Act, 2011, s.68(1) \&(2)

${ }^{7}$ (2008) LPELR-4230(CA)

${ }^{8}$ (1989) NWLR (Pt. 121) 255; (1988) 12 S.C. (Pt. I) 1 - Per DONGBAN-MENSEM, J.C.A. (Pp. 15-16, Paras. D-D) in United Bank for Africa Plc v. Patkan Ventures Limited (2017) LPELR-42392(CA)
} 
tendered, if unchallenged, then it must be acted upon. The document is certainly subject to scrutiny by the trial Court and its contents could, in the process of the scrutiny, be rejected if there is reason to do so, as was done in the present case by the learned trial Judge." Furthermore, in determining whether the court is bound by the expert evidence in the case of Dr. John Olukayode Fayemi v. Olusegun Adebayo Oni \& Anor, ${ }^{1}$ it stated thus: "the evidence of an expert is generally an aspect of the entire evidence to be evaluated by a court because a trial court must be fully in control of all the evidence before it and must not abdicate its primary duty of assessing the evidence and forming its clear opinion in relation thereto, including any expert evidence. In other words, a court is not bound by the evidence of an expert witness, it has an opinion in the matter, that it must exercise judicially and judiciously ....."2

\subsection{Conflicting digital forensic expert evidence}

Obviously, there is the possibility of two or more digital forensic experts giving evidence in the same matter, depending on the number of parties in the case. In which case, the opinion of the experts may vary based on their skills, knowledge, and experience. Under the Nigerian digital forensic expert jurisprudence, where expert evidence given before the Court have conflicting versions on a subject matter, the learned trial judge has the discretion to accept one and discard the other. ${ }^{3}$ In Harrison Odiawa v. Federal Republic of Nigeria $(F R N),{ }^{4}$ the defendant/appellant (Harrison Odiawa) impersonated as Abu Belgore and subsequently arraigned by the EFCC on 58 count of offences, including online fraud; conspiracy to obtain under false pretense; obtaining under false pretense; forgery; uttering and possession of documents containing false pretense contrary to the Advance Fee Fraud and Other Related Offences Act. During the trial, the Prosecution led evidence to show that a solicitation email was sent by the defendant/appellant and his cohorts to one Mr George Robert Blick, an American citizen resident in Virginia, USA, seeking a foreign contractor to facilitate the transfer of \$20.5 million US dollars. The content of the e-mail requested him to respond if he was interested and Mr Blick responded via e-mail where he stated that he had a United States registered corporation that could be used to receive the funds. To facilitate the contract documentation and finalization, the defendant/appellant and his cohorts requested several sums of money from Mr. Blick through exchange of e-mails; telephone conversation and fax i.e 187,000 US dollars (creation of new documents); 10,000 pounds (opening of bank account); 18,750 US dollars (trust processing fee); 410,000 US dollars (payment for issuance of ICP number); 750,000 US dollars (resolution of petition against the transaction); 250,000 US dollars (for Nigerian Minister of Finance before ICP number can be issued; 300,000 Euros (for transportation); 1.5 million US dollars (for repair of damaged part of machine); 1.2 million US dollars (for insurance of machine) - which Mr Blick made available to them. Subsequently, communication between the parties ceased, at this point Mr Blick realized that he had been defrauded and consequently wrote a petition to the EFCC. The defendant/appellant was arrested and later charged before the High Court of Lagos State (No. 40) Ikeja Judicial Division, found guilty of 48 counts, convicted and sentenced. Dissatisfied with the judgment, he appealed before the Court of Appeal. One issue that arose for determination is the identity and/or identification of the person who actually defrauded Mr Blick and whether Abu Belgore is the same person as the defendant/appellant Harrison Odiawa. The defendant/appellant condemned his identification as Abu Belgore by the trial court based on the contents of Exhibit 19. Exhibit 19 is a green bag that was recovered from the appellant's office in the course of the EFCC's operatives or investigators search and raid on the appellant's business premises. Incidentally, some documents addressed to Mr Blick and used to make false representation to him by Abu Belgore were found in the said bag.

In this regard, the court considered the opinion of two expert witnesses who gave contradictory forensic reports and testimonies that were called respectively by the parties. The Prosecution called Muazu Abdullahi (PW5), a staff of the EFCC responsible for the examination and comparative analysis of disputed documents. The defence called Inspector Raphael Onwuzuligbo (DW1), a police inspector attached to the forensic laboratory of the Force Criminal Investigation Department (FCID), Alagbon Close, Lagos. They were both handwriting analysts and Document Examiners called respectively by the Prosecution and the Defence as experts in their field of science to give their opinions based on the comparative analysis of the documents in question sent to them by the parties. Both forensic experts gave forensic expert reports and evidence that were conflicting. One incriminating and the other exonerating the appellant based on the similar disputed documents that they analyzed.

The documents found and recovered in Exhibit 19(the green bag) purported to have been signed and prepared by Abu Belgore and other documents sent to Mr. Blick by Abu Belgore were handed over to the EFCC handwriting expert (PW5). Upon forensic examination of both sets of documents revealed before the court through his forensic report and analysis that they were authored by one and the same person i.e. the appellant. While on the other hand,

\footnotetext{
(2009) LPELR - 4146(CA)

${ }^{2}$ Ibid., PER MUHAMMAD, J.C.A. (Pp. 58-59, paras. F-A)

${ }^{3}$ Harrison Odiawa v. Federal Republic of Nigeria(2008) LPELR-4230(CA) at 37; Elijah Okoh v. The State (1971) 1 NMLR 140; Siesmgraph

Service (Nigeria) Ltd v. Ogdeni (1976) 1 NMLR 290, John Wiberforce Bamiro v. SCOA (1941) 7 WACA 150

${ }^{4}$ Ibid.
} 
the handwriting expert from the police FCID, DW1, concluded that different persons wrote both sets of documents based on his forensic analysis revealed before the court in the course of the criminal proceedings.

Are there grounds or factors that the Courts must put into consideration to discard forensic expert evidence?

For a Court to discard one or the other conflicting expert evidence, it must rely on the following set out grounds:

(a) Where such expert evidence or opinion is illogical and unreasonable

(b) Where the expert fails to provide enough data analysis or basis to support his conclusion;

(c) Where the Court itself makes its own comparison under the Evidence Act and reaches a different conclusion from that of the expert.

(d) Where the expert who claims to have a particular skill in the field in question gives evidence in the Court. However, he fails to give an account of his skill, qualification, or experience in the said field. For which he is called upon to give his opinion. ${ }^{1}$

In Chukwu Const. Co. Ltd v Uwechia, ${ }^{2}$ in determining when the opinion of a hand writing forensic expert can be rejected the Court of Appeal stated per Pat- Acholonu J.C.A.(AHTW): "I think when the court of first instance believes a testimony that is extraordinarily in conflict with reason and probability and is of such a nature that it is hostile to reason as manifestly false an attempt to hoodwink the Court with highfalutin in phrases used by expert writers to bamboozle the court should not make the court fall for such false abracadabra and lend itself to unwholesome belief. Where it does, the Court of Appeal will reverse the order made."3

In Dr. John Olukayode Fayemi v. Olusegun Adebayo Oni \& Anor, ${ }^{4}$ when the Court of Appeal was called upon to resolve the issue whether the existence of other credible evidence would constitute a good reason to reject an expert evidence, it stated thus: "The existence of other relevant and credible evidence before the court showing that the evidence of the expert is not or cannot be true will constitute a good reason for rejecting it. A trial judge would be right to prefer credible evidence of a non-expert witness on an issue to the evidence of an expert on the same issue where the former is an independent witness whilst the latter prepared his evidence specifically for the case on hand on the direction of the party calling him."5

In further substantiation of the legality of Courts to rejecting digital forensic evidence of an expert witness, the Court in A.N.P.Pv. Usman, ${ }^{6}$ stated that: "The Court must be wary of admitting a report prepared by an expert, not at the instance of the Court but at the behest of any of the parties to the dispute. Such a report should be taken with a pinch of salt. The existence of other relevant and credible evidence before the Court showing that the evidence of the expert is not or cannot be true will constitute a good reason for rejecting it."7

Questions of the integrity of digital forensic experts is another reason for rejecting the evidence of forensic expert witnesses. For instance, in Akeredolu v. Mimiko \& Ors ${ }^{8}$ the Nigerian Supreme Court stated that "the court is not bound to accept the evidence of any expert, even one who has not disclosed incentive or motive other than helping the court in the quest for justice. Therefore, when an expert witness, by his own ipsa dixit, portrays himself as one hawking his evidence or a mercenary who would fight any man's battle for a fee as it were, gives evidence in court, the court has a duty to treat his evidence with the disdain it deserves. Thus, the appeal in this case was rejected and dismissed. ${ }^{9}$

\subsection{Demonstration of digital forensic evidence in Court}

A digital forensic expert who is desirous of demonstrating how he or she arrived at his or her opinion in Court will do well to ensure that he lays the proper foundation by informing the Court either through an affidavit and showing the condition of the electronic gadget or computer sought to be used. This may also involve bringing a formal written application before the Court seeking the leave of the Court to demonstrate electronically before the Court how the forensic evidence or report was arrived at. Failure on the part of a party to lay the proper foundation would necessitate the Court to refuse such demonstration in Court. The Nigerian Supreme Court in Akeredolu v. Mimiko \& $O r s^{10}$ stated thus: "Going by the foregoing provision it is discernible that the appellants who were desirous of demonstrating electronically the content of Exhibits P50A and P50B failed to lay the necessary foundation regarding the condition of the electronic gadget or computer they were going to use." To the extent that those

\footnotetext{
${ }^{1}$ Ibid.; Aladu v. State (1998) 8 NWLR (Pt.563) 618; VAU Tittidabale v. Sokoto NA (1964) 1 Nigerian Law Journal, page 123; (1964) NNLR;

UTB v. Awanzigana Enterprises (1994) 6 NWLR (pt 348) 58.

2 (2000) 2 NWLR (Pt 643) Pg 92 at 99 Paras, E -F

${ }^{3}$ Ibid.,; see also Okoye v. Kpajie (1973) NMLR 84; Fashanu v. Adekoya (1974) 6 S.c. P. 83.

4 (2009) LPELR - 4146(CA)

${ }^{5}$ See also ELF (NIG. Ltd v. SILLO (1994) 6 NWLR (Pt. 350) page 258, PER MUHAMMAD, J.C.A. (Pp. 57-58, paras. F-A)

${ }^{6}$ Per TSAMMANI, J.C.A. (P . 68, Paras. A-F) at p. 73

${ }^{7}$ Ibid

8 (2013) LPELR- 21413(SC) Per Ngwuta JSC.

${ }^{9} \mathrm{Ibid}$, ("It is unsafe to rely on the report put in by an expert for a fee. Such an expert witness can be declared unreliable and his evidence declared as one which cannot enhance the case of the party on whose behalf he gave evidence. ..If the evidence of PW35 was found to be "'preposterous, outlandish and perverse", that of PW34 was outright dishonest and shameful as he admitted under cross-examination to have been briefed upon a fee "to look for evidence to sustain the petition that was already filed.")

${ }^{10}$ (2013) LPELR- 21413(SC) Per Ngwuta JSC.
} 
conditions as spelt out in section 84 supra were unfulfilled, the demonstration ought not be allowed..."

\section{Conclusion}

This paper shows how information and communication technology has resulted in the application of digital devices by Nigerians and the nature of the impact it generally has. As the paper note, the absence of an initial legal framework concerning the admissibility of digital documents led to a slow development towards digital forensic and its practice in Nigeria. Sequel to the enactment of the Nigerian Evidence Act 2011, Cybercrimes Act 2015, and the Administration of Criminal Justice Act 2015, the application of digital forensic evidence has become inevitable in the Nigerian Courts. The principal question that the paper has answered is the nature and attitude of Courts concerning digital forensic experts and forensic evidence presented by them in the course of proceedings. Although most of the issues are discerned from decisions handed down by Courts, there is a need for the Nigerian government to enact a separate law to regulate digital forensic and digital expert evidence. As it stands, the position or attitude of Courts on digital

Forensic and expert witnessing is at the discretion and whims and caprices of the Courts. Unless an urgent step is taken, a Court that is not desirous of considering the evidence of an expert witness will look for a reason to reject the same.

\section{REFERENCES}

- A Road Map for Digital Forensic Research, Report from the First Digital Forensic Research Workshop (DFRWS), available at http://dfrws. org/2001/dfrws-rm-final.pdf in Ovie L Carroll and Stephen K Brannon and Thomas Song, 'Computer Forensics: Digital Forensic Analysis Methodology' (2008) 56 United States Attorneys' Bulletin 1

- $\quad$ Administration of Criminal Justice Act 2015, ss. 15(4) \& 17(1) \&(2); Nwakuche Jerry Nnjiofor v, The Federal Republic of Nigeria(2018) LPELR - 43925

- $\quad$ Andre A Moenssens, 'Handwriting Identification Evidence in the Post-Daubert World' (1997) 66 UMKC Law Review, 251, 256

- $\quad$ Andre A Moenssens, 'Handwriting Identification Evidence in the Post-Daubert World' (1997) 66 UMKC Law Review, 251, 256

- Criminal Justice Degree Schools, Forensic Ballistics Expert: Career Guide, available at $<$ https://www.criminaljusticedegreeschools.com/criminal-justice-careers/forensic-ballisticsexpert/\#: :targetText=Forensic $\% 20$ ballistics $\% 20$ is $\% 20$ the $\% 20$ examination,others $\% 20$ involved $\% 20 \mathrm{in} \% 20 \mathrm{a}$ $\% 20$ case $>$.Last accessed 18 November 2019.

- $\quad$ Daniel Ogden, 'Mobile Device Forensics: Beyond Call Logs and Text Messages' (2017) 65 United States Attorneys' Bulletin, 11

- Daniel Ogden, 'Mobile Device Forensics: Beyond Call Logs and Text Messages' (2017) 65 United States Attorneys' Bulletin, 11; Andrew McQuilkin, 'Sleeping Gate-Keepers: Challenging the Admissibility of Cell Phone Forensic Evidence Under Daubert' (2011) 11 Journal of High Technology Law, 365, 372

- F.E. Eboibi, Cybercrime Prosecution and The Nigerian Evidence Act, 2011: Challenges of Electronic Evidence, 10 Nigerian Law and Practice Journal (2011) 139 - 160 \& F.E. Eboibi, Chapter 2 - Introduction to Law \& Cybercrime F.E. Eboibi(ed), Handbook on Nigerian Cybercrime, Benin: Justice Jeco Printing \& Publishing Global, 2018, 223 - 245

- F.E. Eboibi, Cybercrime Prosecution and The Nigerian Evidence Act, 2011: Challenges of Electronic Evidence, 10 Nigerian Law and Practice Journal (2011) 139 - 160

- $\quad$ F.E. Eboibi, Introduction to Law \& Cybercrime in F.E. Eboibi(ed), Handbook on Nigerian Cybercrime, Benin: Justice Jeco Printing \& Publishing Global, 2018, 25-26; F.E Eboibi, 'Enforcement of Cybercrime in Nigeria: Are

- Jay V Miller, 'The FBI's Forensic DNA Analysis Program' (1991) 60 FBI Law Enforcement Bulletin,11 - .('DNA analysis' means analysis of the deoxyribonucleic acid (DNA) identification information in a bodily sample")

- Jay V Miller, 'The FBI's Forensic DNA Analysis Program' (1991) 60 FBI Law Enforcement Bulletin, 11; David H Kaye, 'Trawling DNA Databases for Partial Matches: What is the FBI Afraid of' (2009) 19 Cornell Journal of Law and Public Policy, 145

- John W Bond, 'The Value of Fingerprint Evidence in Detecting Crime' (2009) 11 International Journal of Police Science Management, 77

- $\quad$ Kehinde Adegbite, Law and Forensic: Techniques of Evidence Gathering and Case Presentation in Court, 11 October 2014, available at < http://www.nigeriavillagesquare.com/articles/law-and-forensic-techniques-of-

${ }^{1}$ (2013) LPELR- 21413(SC) 
evidence-gathering-and-case-presentation-in-court.html $>$ Last accessed 10 October 2018

- $\quad$ Phiip O. Nwachukwu, Admissibility of the Opinion of a Computer Forensics Examiner as Expert Evidence under Nigeria Law of Evidence.

- $\quad$ The Nigerian Evidence Act 1945 was reproduced as Cap E14, Laws of the Federation of Nigeria, 2004 now repealed by the Evidence of 2011, Section 68

\section{CASES}

- $\quad$ Aladu v. State (1998) 8 NWLR (Pt.563) 618; VAU Tittidabale v. Sokoto NA (1964) 1 Nigerian Law Journal, page 123; (1964) NNLR; UTB v. Awanzigana Enterprises (1994) 6 NWLR (pt 348) 58.

- $\quad$ Elijah Okoh v. The State (1971) 1 NMLR 140;

- $\quad$ Fashanu v. Adekoya (1974) 6 S.c. P. 83.

- Harrison Odiawa v. Federal Republic of Nigeria(2008) LPELR-4230(CA) at 37;

- John Wiberforce Bamiro v. SCOA (1941) 7 WACA 150

- Ogwa Nweke Onah v. The State(1985) LPELR-2668(SC)

- $\quad$ Okoye v. Kpajie (1973) NMLR 84;

- $\quad$ R. v. Onitiri (1946) 12 WACA 58

- $\quad$ Shonubi v. People of Lagos State (2015) All FWLR (pt. 801) at 1424, 1432 to1433

- $\quad$ Siesmgraph Service (Nigeria) Ltd v. Ogdeni (1976) 1 NMLR 290,

- $\quad$ The Queen v. Akpan (1961) 1 All NLR 3

- $\quad$ Trade Bank v.Chami (2003) 13 NWLR (pt.836) 158

- UBA vs. Sani Abacha Foundation for Peace and Unity (SAPFU) (2004) 3 NWLR Numba Commercial Farms Ltd \& Anor vs. Nal Merchant Bank Ltd \& Anor (2001) 16 NWLR (pt. 740) 510. 